\title{
HUBUNGAN POLA ASUH ORANG TUA DENGAN KEPERCAYAAN DIRI SISWA SMP KRISTEN RANOTONGKOR KABUPATEN MINAHASA
}

\author{
${ }^{1}$ Nathania Longkutoy \\ ${ }^{2}$ Jehosua Sinolungan \\ ${ }^{2}$ Henry Opod \\ ${ }^{1}$ Kandidat Skripsi Fakultas Kedokteran Universitas Sam Ratulangi Manado \\ ${ }^{2}$ Bagian Psikologi Fakultas Kedokteran Universitas Sam Ratulangi Manado \\ Email:longkutoy.nathania@yahoo.com
}

\begin{abstract}
Self-confidence is one of the important aspects of a person's personality, including students at the school in stages of development into adulthood. One of the factors that influence the formation of self-confidence is parenting styles. This study aimed to determine the relationship between parenting styles with student's self confidence. This research is an analytical quantitative research methods. Sampling in this study are 50 students of SMP Kristen Ranotongkor. The data was collected with questionnaires. The result showed that there was a significant relationship between parenting styles and self-confidence among the students of SMP Kristen Ranotongkor with $\mathrm{p}=0,015(\mathrm{p}<\alpha=0,05)$ and the correlation value is 0,343 . It means that the democratic parenting applied, the higher the level of self-confidence. In conclusion, there was a positive relationship between parenting styles and self-confidence of the students in SMP Kristen Ranotongkor Kabupaten Minahasa.
\end{abstract}

Keywords: parenting styles, self-confidence.

\begin{abstract}
Abstrak: Kepercayaan diri merupakan salah satu aspek kepribadian yang penting bagi seseorang termasuk siswa di sekolah dalam tahapan perkembangan menjadi dewasa. Salah satu faktor yang mempengaruhi kepercayaan diri adalah pola asuh orang tua. Penelitian ini bertujuan untuk mengetahui hubungan pola asuh orang tua dengan kepercayaan diri siswa. Penelitian ini bersifat analitik kuantitatif. Sampel dalam penelitian ini adalah 50 siswa SMP Kristen Ranotongkor. Pengambilan data melalui kuesioner. Hasil penelitian menunjukkan ada hubungan yang signifikan antara pola asuh orang tua dengan kepercayaan diri siswa SMP Kristen Ranotongkor dengan nilai $\mathrm{p}=0,015(\mathrm{p}<\alpha=0,05)$ dan nilai korelasi sebesar 0,343. Artinya, semakin demokratis pola asuh yang diterapkan, semakin tinggi tingkat kepercayaan diri. Dapat disimpulkan bahwa terdapat hubungan positif antara pola asuh orang tua dengan kepercayaan diri.
\end{abstract}

Kata kunci: pola asuh orang tua, kepercayaan diri.

Setiap perkembangan anak merupakan suatu proses yang kompleks, tidak dapat terbentuk hanya dari dalam diri anak saja, tetapi juga lingkungan tempat tinggal anak.
Lingkungan yang pertama dan paling berpengaruh adalah lingkungan keluarga, dimana orang tua sangat berperan di dalamnya. Habibi menjelaskan bahwa masa 
depan anak sangat tergantung dari pengalaman yang didapat anak termasuk faktor pendidikan dan pola asuh orang tua. ${ }^{7}$

Diana Baumrind mengemukakan bahwa pola asuh merupakan segala bentuk dan proses interaksi yang terjadi antara orang tua dan anak yang merupakan pola pengasuhan tertentu dalam keluarga yang akan memberikan pengaruh terhadap perkembangan kepribadian anak. Lebih lanjut Baumrind mengatakan terdapat tiga bentuk pola asuh orang tua yaitu pola asuh authoritative (demokratis), authoritarian (otoriter) dan permissive.,

Pola asuh otoriter yang ditandai dengan orang tua yang melarang anaknya dengan mengorbankan otonomi anak. Ciriciri pola asuh otoriter antara lain sikap orang tua yang kaku dan keras dalam menerapkan peraturan maupun disiplin, orang tua bersikap memaksa dan selalu menuntut kepatuhan anak. Pola asuh demokratis ditandai dengan adanya sikap terbuka antara orang tua dan anak. Orang tua yang demokratis adalah orang tua yang menghargai kemampuan anak secara langsung. Ditandai dengan sikap menerima, responsif, berorientasi pada kebutuhan anak yang disertai tuntutan, kontrol dan pembatasan. Pola asuh permisif ditandai dengan adanya kebebasan tanpa batas dari orang tua terhadap anak untuk berbuat dan berperilaku sesuai keinginan anak. Orang tua pada pola asuh ini cenderung kurang hangat, kurang mengasihi dan kurang simpatik pada anak-anaknya., ${ }^{2,12}$

Penelitian yang telah dilakukan dalam beberapa tahun terakhir, pada remaja di Iran tahun 2012 didapati bahwa pola asuh orang tua mempengaruhi kesehatan mental, harga diri dan kualitas hidup anak. ${ }^{7}$ Selain itu, penelitian yang dilakukan di Malaysia pada tahun 2010 juga mendapati adanya bahwa pola asuh orang tua mempengaruhi prestasi anak. ${ }^{6} \mathrm{Hal}$ ini membuktikan bahwa pola asuh orang tua merupakan faktor penting yang mempengaruhi perkembangan anak sampai dia menjadi dewasa, termasuk dalam hal kepercayaan diri.

Menurut Lauster, kepercayaan diri adalah salah satu aspek kepribadian atau konsep diri yang penting bagi seseorang dikarenakan dengan adanya kepercayaan diri seseorang mampu mengaktualisasikan segala potensi yang ada pada dirinya. Berdasarkan pendapat tersebut maka dapat diketahui bahwa kepercayaan diri tidak hanya harus dimiliki oleh orang dewasa tapi juga remaja dalam perkembangan mereka menjadi dewasa agar mampu berinteraksi dengan orang lain sehingga dapat menciptakan interaksi sosial yang positif. $^{3}$

Guilford mengemukakan bahwa ciriciri kepercayaan diri dapat dinilai melalui tiga aspek, yaitu merasa adekuat terhadap tindakan yang dilakukan, merasa diterima oleh lingkungan dan memiliki ketenangan sikap. ${ }^{9}$

Rasa percaya diri dapat diwujudkan melalui sikap berani dan yakin dalam melakukan sesuatu. Namun fenomena yang terlihat saat ini, masalah yang muncul pada siswa-siswa di sekolah berhubungan dengan kurangnya rasa kepercayaan diri. Hal ini terlihat lewat kurangnya motivasi untuk berkompetisi, tidak ada keberanian menyampaikan pendapat didepan umum dan ragu-ragu untuk menjawab

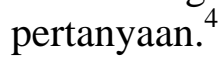

Berdasarkan penelitian Muhammad Idrus dan Anas Rohmiati yang berjudul Hubungan Kepercayaan Diri Remaja dengan Pola Asuh Orang Tua Etnis Jawa, menunjukkan bahwa ada hubungan positif yang sangat signifikan antara pola asuh mendorong orang tua Jawa (demokratis) dengan tingkat kepercayaan diri remaja dimana hasil analisis data menunjukkan korelasi antara variabel pola asuh dan kepercayaan diri nilai $r=0,419$ dan nilai $\mathrm{p}$ $=0,000(\mathrm{p}<0,01)^{5}$

Survey awal yang dilakukan lewat wawancara dengan guru Bimbingan Konseling di SMP Kristen Ranotongkor, didapatkan bahwa ada perbedaan antara siswa-siswa dengan rasa percaya diri yang tinggi dan siswa-siswa yang kurang percaya diri. Dimana terdapat beberapa siswa yang enggan untuk maju kedepan kelas ketika diminta untuk berdoa juga ketika diminta untuk ikut dalam lomba 
antar sekolah. Hal ini terjadi beberapa kali. Padahal mereka cukup pintar dalam kemampuan kognitif dan sains. Sangat berbeda dengan siswa-siswa lain yang begitu antusias ketika diminta tampil di depan umum untuk memimpin upacara dan mengikuti lomba-lomba antar sekolah.

Berdasarkan landasan pemikiran tersebut, peneliti ingin mencari tahu apakah ada hubungan antara pola asuh orang tua dengan kepercayaan diri pada siswa SMP Kristen Ranotongkor Kabupaten Minahasa.

\section{METODOLOGI PENELITIAN}

Penelitian ini bersifat analitik kuantitatif dengan pendekatan cross sectional. Penelitian ini dilaksanakan di SMP Kristen Ranotongkor Kabupaten Minahasa pada bulan Desember 2014. Populasi dalam penelitian ini ialah seluruh siswa SMP Kristen Ranotongkor sejumlah 89 siswa. Besar sampel dalam penelitianini ditentukan dengan menggunakan rumus slovin, dan dengan menggunakan perhitungan response rate diperoleh 50 sampel.

Metode yang digunakan dalam penelitian ini adalah simpel random sampling. Variabel dalam penelitian ini yaitu pola asuh orang tua dan kepercayaan diri. Penelitian ini menggunakan kuesioner pola asuh orang tua yang terdiri dari 27 pertanyaan dan kuesioner kepercayaan diri yang terdiri dari 26 pertanyaan, dengan pilihan jawaban menggunakan skor skala likert.

Analisis data dengan program komputerdan menggunakan teknik analisis korelasi Spearman Rank. ${ }^{11}$

\section{HASIL DAN PEMBAHASAN Analisis Univariat}

Tabel 1. Distribusi responden berdasarkan pola asuh orang tua

\begin{tabular}{rcc}
\hline Kategori & Responden & $\mathbf{( \% )}$ \\
\hline Otoriter & 14 & 28 \\
Demokratis & 25 & 50 \\
Permisif & 11 & 22 \\
\hline Total & 50 & 100 \\
\hline
\end{tabular}

Tabel diatas menunjukkan gambaran tipe pola asuh orang tua pada siswa SMP Kristen Ranotongkor yang paling banyak diterapkan adalah pola asuh demokratis dengan persentase 50\% (25 responden).

Tabel 2. Distribusi responden berdasarkan kepercayaan diri

\begin{tabular}{rcc}
\hline Kategori & Responden & $\mathbf{( \% )}$ \\
\hline Tinggi & 32 & 64 \\
Cukup & 15 & 30 \\
Rendah & 3 & 6 \\
\hline Total & 50 & 100 \\
\hline
\end{tabular}

Tabel 2 menunjukkan distribusi responden berdasarkan tingkat kepercayaan diri. Siswa SMP Kristen Ranotongkor terbanyak memiliki tingkat kepercayaan diri tinggi yaitu sebesar 64\% (32 responden).

Tabel 3.Tabulasi silang pola asuh orang tua dengan kepercayaan diri

\begin{tabular}{ccccc}
\hline \multirow{2}{*}{$\begin{array}{c}\text { Pola asuh } \\
\text { orang tua }\end{array}$} & \multicolumn{2}{c}{ Tingkat Kepercayaan Diri } & \multirow{2}{*}{ Total } \\
\cline { 2 - 4 } & Tinggi & Cukup & Rendah & \\
\hline Otoriter & $9(28,1 \%)$ & $4(26,7 \%)$ & $1(33,1 \%)$ & $14(28 \%)$ \\
Demokratis & $22(66,8 \%)$ & $3(20,0 \%)$ & $0(0 \%)$ & $25(50 \%)$ \\
Permisif & $1(3,1 \%)$ & $8(53,3 \%)$ & $2(66,7 \%)$ & $11(22,0 \%)$ \\
Total & $32(100 \%)$ & $15(100 \%)$ & $3(100 \%)$ & $50(100 \%)$ \\
\hline
\end{tabular}


Tabel 3 menunjukkan hasil pengkategorian tingkat kepercayaan diri tinggi, cukup dan rendah berdasarkan tipe pola asuh orang tua. Terdapat 9 responden dengan pola asuh otoriter (28,1\%), 22 responden dengan pola asuh demokratis (68,8\%) dan 1 responden dengan pola asuh permisif $(3,1 \%)$ yang memiliki tingkat kepercayaan diri yang tinggi. Sementara itu tingkat kepercayaan diri cukup terdapat pada 4 responden pola asuh otoriter (26,7\%), 3 responden pola asuh demokratis (20\%) dan pada 8 responden dengan pola asuh permisif (53,3\%). Untuk kepercayaan diri rendah terdapat pada 1 responden dengan pola asuh otoriter (33,3\%) dan 2 responden dengan pola asuh permisif $(66,7 \%)$.

\section{Analisis Bivariat}

Tabel 4. Hubungan antara pola asuh orang tua dengan kepercayaan diri

\begin{tabular}{ccccc}
\hline & & $\begin{array}{c}\text { Pola asuh } \\
\text { orang tua }\end{array}$ & $\begin{array}{c}\text { Kepercayaan } \\
\text { diri }\end{array}$ \\
\hline & Pola asuh & Correlation & 1.000 & $.343^{*}$ \\
orang tua & Coefficient & Sig. (2-tailed) &. & .015 \\
Spearman's & & $\mathrm{N}$ & 50 & 50 \\
& & Correlation & $.343^{*}$ & 1.000 \\
& Kepercayaan & Coefficient & diri & Sig. (2-tailed) \\
& & $\mathrm{N}$ & .015 &. \\
& & & 50 & 50 \\
\hline
\end{tabular}

Hasil uji statistik spearman rank pada tabel 4menunjukkan nilai koefisien korelasi $r=0,343$ yang menggambarkan tingkat kekuatan hubungan antara variable pola asuh orang tua dan kepercayaan diri. Berdasarkan kriteria pedoman koefisien korelasi, nilai tersebut termasuk pada kategori rendah. Tanda positif menunjukkan arah hubungan korelasi, yaitu pola asuh orang tua berbanding lurus dengan kepercayaan diri siswa.

Hasil uji hipotesis dapat dinilai dari taraf signifikansi dimana nilai signifikasi $\mathrm{p}$ $=0,015$ pada taraf kepercayaan $\alpha=0,05$. Berdasarkan analisis data diketahui nilai $\mathrm{p}$ $<0,05$. Hasil tersebut menunjukkan bahwa terdapat hubungan positif yang signifikan antara pola asuh orang tua dengan kepercayaan diri siswa.

Berdasarkan hasil analisis yang telah dilakukan menunjukkan bahwa ada hubungan positif yang signifikan antara pola asuh orang tua dengan kepercayaan diri siswa. Semakin demokratis pola asuh yang diterapkan orang tua, makin tinggi kepercayaan diri yang dimiliki anak. Hasil analisis tersebut menunjukkan nilai koefisien korelasi sebesar 0,343 dengan nilai signifikansi $\mathrm{p}=0,015(\mathrm{p}<0,05)$. Adanya korelasi tersebut menunjukkan bahwa pola asuh orang tua berperan dalam pembentukan kepribadian seseorang termasuk dalam pembentukan kepercayaan diri.

Data yang diperoleh menunjukkan sebanyak 50\% anak di SMP Kristen Ranotongkor mendapatkan pola asuh demokratis. Itu berarti bahwa model pengasuhan yang paling banyak diterapkan adalah pola asuh demokratis. Aspek-aspek yang terkandung dalam pola asuh demokratis seperti yang diungkapkan dalam teori Hurlock antara lain orang tua yang bersikap rasional, melibatkan anak dalam pengambilan keputusan serta memberi kesempatan pada anak untuk mandiri tanpa mengabaikan kontrol pada anak dengan pendekatan yang hangat, akan memberikan dampak positif pada perkembangan anak, seperti anak memiliki 
rasa tanggung jawab dan mampu menyesuaikan diri dengan lingkungan sekitar sehingga berdampak pada peningkatan rasa percaya diri anak. Hal tersebut terjadi karena orang tua dengan pola asuh demokratis selalu memberikan penjelasan yang logis pada tiap aturan yang diberikan pada anak sehingga anak mempergunakan kebebasan yang diberikan orang tua dengan bertanggung jawab. Ini sesuai dengan hasil tabulasi silang dalam penelitian antara pola asuh orang tua dengan tingkat kepercayaan diri dengan hasil sebanyak 22 responden (68,8\%) dengan pola asuh demokratis memiliki tingkat kepercayaan diri yang tinggi dan hanya 3 responden (20\%) yang memiliki tingkat kepercayaan diri cukup dan tidak ada yang memiliki tingkat kepercayaan diri rendah.

Hal tersebut sesuai dengan penelitian yang dilakukan oleh Nirwana yang menyatakan bahwa terdapat hubungan yang positif antara pola asuh orang tua dengan kepercayaan diri siswa dengan asumsi semakin tinggi pola asuh orang tua demokratis pada anaknya, maka semakin tinggi tingkat kepercayaan diri siswa. ${ }^{8}$ Sementara itu, penelitian yang dilakukan di Farhangian University Iran oleh Niaraki dan Rahimi juga membuktikan bahwa ada perbedaan yang signifikan antara pola asuh demokratis dengan pola asuh otoriter maupun permisif yang diterapkan orang tua pada anak. Seorang anak dengan pola asuh demokratis cenderung memiliki konsep diri bahkan kualitas hidup yang lebih baik daripada anak yang diasuh dengan pola pengasuhan otoriter atau permisif. ${ }^{7}$

Hasil penelitian juga menunjukkan sebanyak 28\% responden mendapatkan gaya pengasuhan otoriter dari orang tua mereka. Teori yang dikemukakan oleh Baumrind mengatakan bahwa orang tua yang menerapkan pola asuh otoriter cenderung bersikap kaku dan keras, suka memaksakan kehendak dan selalu menuntut kepatuhan anak. Otoritas yang ditunjukkan orang tua tersebut membuat anak sedikit mendapatkan kesempatan untuk mengemukakan pendapat dan mengambil keputusan sehingga anak cenderung menjadi penurut, lebih tertutup, tidak berinisiatif dan pemalu. Hal ini sesuai dengan hasil tabulasi silang yang mendapati bahwa terdapat 4 responden (26,7\%) dengan pola asuh otoriter yang memiliki tingkat kepercayaan diri cukup dan 1 responden (33,3\%) dengan tingkat kepercayaan diri rendah.

Pola asuh permisif juga ditemui pada beberapa anak di SMP Kristen Ranotongkor. Pada penelitian terlihat sebanyak $22 \%$ orang tua menerapkan pola asuh permisif pada anak-anak mereka. Baumrind menyatakan orang tua dengan pola asuh permisif bersikap tidak peduli serta memberikan kebebasan penuh pada anak untuk berbuat dan berperilaku sesuai keinginan anak. Orang tua menganggap anak seperti orang dewasa yang dapat mengambil tindakan atau keputusan sendiri. Contohnya orang tua yang membiarkan anak pulang larut malam. Menurut Wong $d k k$ dalam penelitiannya, tidak adanya arahan dan aturan dalam pola asuh ini mengakibatkan anak menjadi tidak patuh, manja dan tidak bertanggung jawab. Selain itu, tidak adanya kontrol dari orang tua mengakibatkan anak merasa cemas dengan tindakan yang mereka lakukan apakah salah atau benar, sehingga keyakinan akan kemampuan diri anak tersebut tidak berkembang dan anak cenderung menjadi kurang percaya diri. ${ }^{10}$ Hal ini didukung dengan hasil tabulasi silang yang diperoleh yaitu sebanyak 8 responden $(53,3 \%)$ memiliki rasa percaya diri cukup, 2 responden (66,7\%) dengan tingkat kepercayaan diri rendah dan hanya 1 responden $(3,1 \%)$ yang memiliki tingkat kepercayaan diri yang tinggi. Dengan demikian dikatakan bahwa pola asuh demokratis lebih efektif untuk diterapkan dibandingkan dengan pola asuh otoriter atau permisif.

Sesuai dengan teori Hurlock, ada beberapa faktor yang terlibat dan mempengaruhi pola asuh orang tua pada anak mereka, antara lain latar belakang pola pengasuhan orang tua yaitu model pengasuhan yang diterima oleh orang tua 
sebelumnya dan dipandang berhasil, tingkat pendidikan orang tua serta status ekonomi dan pekerjaan orang tua juga menjadi faktor yang mempengaruhi pola asuh seseorang.

Namun demikian, pembentukan kepercayaan diri seseorang tidak hanya dipengaruhi oleh pola asuh orang tua. Liendenfield mengungkapkan ada beberapa faktor yang mempengaruhi pembentukan kepercayaan diri seseorang seperti status sosial ekonomi, penampilan fisik, dan tingkat pendidikan. ${ }^{1}$ Faktor-faktor tersebut yang dapat menjadi penyebab anak dengan pola asuh orang tua otoriter ataupun permisif tetap memiliki tingkat kepercayaan diri yang tinggi.Terlihat dalam hasil tabulasi silang dari penelitian yang telah dilakukan di SMP Kristen Ranotongkor, terdapat 9 responden $(28,1 \%)$ yang mendapat pola asuh otoriter dari orang tua memiliki rasa percaya diri yang tinggi. Itu berarti rasa percaya diri siswasiswa tersebut tidak hanya terbentuk lewat pola asuh yang diterapkan oleh orang tua, namun ada hal-hal lain yang ikut berperan didalamnya.

Melalui pembahasan ini dapat diketahui bahwa ada begitu banyak faktor yang mempengaruhi terbentuknya pola asuh orang tua dan yang mempengaruhi tingkat kepercayaan diri seseorang namun sesuai dengan hasil penelitian yang dilakukan, pola asuh orang tua memiliki kontribusi yang besar dalam pembentukan kepercayaan diri karena pola asuh orang tua sudah mempengaruhi seseorang sejak berada di lingkungan yang pertama yaitu lingkungan keluarga.

\section{SIMPULAN DAN SARAN}

Berdasarkan hasil penelitian dapat disimpulkan bahwa ada hubungan positif yang signifikan antara pola asuh orang tua dengan kepercayaan diri siswa SMP Kristen Ranotongkor dengan nilai $\mathrm{p}=$ 0,015 dengan demikian nilai $\mathrm{p}<0,05$ yang artinya semakin demokratis pola asuh orang tua yang diberikan maka akan semakin tinggi juga kepercayaan diri yang dimiliki.
Saran bagi orang tua, diharapkan untuk mengevaluasi dan lebih memperhatikan cara pengasuhan anak. Bagi institusi, penelitian ini diharapkan dapat menjadi salah satu referensi terkait hubungan antara tipe pola asuh orang tua dengan tingkat kepercayaan diri siswa dalam penerapannya dalam proses pendidikan. Bagi peneliti selanjutnya diharapkan dapat mengembangkan penelitian terkait dengan variabel-variabel yang lain.

\section{DAFTAR PUSTAKA}

1. Fatchurahman $M$, Pratikto $H$. Kepercayaan diri, kematangan emosi, pola asuh orang tua demokratis dan kenakalan remaja. Persona, Jurnal psikologi Indonesia. 2012;01(2):77-87.

2. Fatimah L. Hubungan persepsi anak terhadap keharmonisan keluarga dan pola asuh orang tua dengan motivasi belajar. [thesis]. Surakarta: Universitas Sebelas Maret; 2010.

3. Herlambang ASU, Lilik S, Agustin RW. Perbedaan kepercayaan diri pada siswa dengan perilaku bermasalah ditinjau dari pola asuh orang tua di SMAN 1 Kauman Tulungagung. [serial online]. 2013 [cited 2014 Oct 24];02(1):1-9. Available from: http://candrajiwa.psikologi.fk.uns.ac.id/ index.php/candrajiwa/article/view/44

4. Husnatul J. Bentuk pola asuh orang tua dalam menanamkan perilaku moral pada anak usia dini dikecamatan Ampek Angkek. Pesona PAUD. 2012;01(1):1-10.

5. Idrus M, Rohmiati A. Hubungan kepercayaan diri remaja dengan pola asuh orang tua etnis Jawa. [homepage in the internet]. c2011. [Updated 2011 June 15 2014, cited 2014 Oct 25]. Available from: http://kajian.uii.ac.id/wpcontent/uploads/2011/06/HUBUNGAN -KEPERCAYAAN-DIRI-REMAJADENGAN_DR-M-IDRUS-DKK.pdf

6. Kordi A, Baharudin R. Parenting attitude and style and its effect on children's school achievements. International journal of psychological studies. 2010;02(2):217-22.

7. Niaraki FR, Rahimi $\mathbf{H}$. The impact of authoritative, permissive and 
authoritarian behavior of parents on self concept, psychological health and life quality. Europan online journal of natural and social sciences. 2013;02(1):78-85.

8. Nirwana. Konsep diri, pola asuh orang tua demokratis dan kepercayaan diri siswa. Persona, Jurnal Psikologi Indonesia. 2013;02(2):153-61.

9. Saputro ND, Suseno MN. Hubungan antara kepercayaan diri dengan employability pada mahasiswa. Jurnal Psikologi [serial online]. 2010 [cited 2014 Oct 26];03(1):1-8. Available from:

http://psikohumanika.setiabudi.ac.id/in dex.php?option=com_alphacontent\&vi ew $=$ alphacontent $\&$ Itemid $=70$

10.Sari AP. Hubungan pola asuh orang tua dengan kepercayaan diri pada anak prasekolah (3-5 tahun) di TK IV Saraswati Denpasar tahun 2012. [homepage on the internet]. c2013 [cited 2015 Jan 10]. Available from: https://www.google.com/url?sa=t\&rct= $\mathrm{j} \& \mathrm{q}=\&$ esrc $=\mathrm{s} \&$ source $=$ web $\& \mathrm{~cd}=1 \& \mathrm{ca}$ $\mathrm{d}=$ rja\&uact $=8 \&$ ved $=0 \mathrm{CB} 0 \mathrm{QFjAA} \& u r \mathrm{r}$ =http $\% 3 \mathrm{~A} \% 2 \mathrm{~F} \% 2$ Fojs.unud.ac.id $\% 2 \mathrm{Fi}$ ndex.php\%2Fcoping\%2Farticle\%2Fdo wnload\%2F6470\%2F4985\&ei=ply7VP XtL-

jGmAW90ICACQ\&usg=AFQjCNGM 6X7cnQYmlmYd8jfDNgQv7cnBcg\&s ig2=Km3-KH6ZITzSj5OcJlCEQ\&bvm=bv.83829542,d.c2E

11.Sujarweni VW. SPSS untuk penelitian. Yogyakarta: Pustaka Baru Press, 2014.

12.Wentzel K, Russell S. Parenting Styles [homepage on the internet]. c2009. [Updated 2009 Dec 23, cited 2014 Oct 12]. Available from: http://www.education.com/reference/ar ticle/parenting-styles1/ 